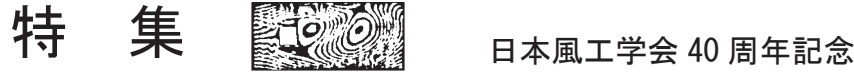

\section{日本風工学会誕生の頃 \\ The Early Days of Japan Association for Wind Engineering}

伊藤 學*

Manabu ITO

私が初めて風工学分野の活動に加わったのはほぼ半世 紀前の 1967 年, オタワにおける 2nd International Seminar on Wind Effects on Buildings and Structures への参加であつ た。大学院から助教授時代初期にかけての私の研究テー マは吊橋の振動とは言っても走行荷重を対象としたもの であったが，1964 年，私の上司，平井 敦教授の念願叶 って全径間橋梁模型用大型風洞が東大橋梁研究室に設置 されるに及び，私もそちらの研究グループに加わった。 平井先生は戦時中の 1940 年末, ニュース映画で旧タコマ 橋落橋のシーンを見て, いち早く吊橋の耐風安定性の研 究に着手されたという，この分野の世界的パイオニアで あった。橋梁風荷重の研究は既に 19 世紀末の英国フォー ス鉄道橋の設計時に手がけられていたが，国際交流の本 格的スタートは 1963 年, 上記オタワ会議と同じテーマの 第 1 回国際会議の英国での開催であった。 4 年毎開催とな ったこの会議の第 3 回は 1971 年, 平井先生が組織委員長, 私が幹事を務め, 東京に招致された。この会議が風工学 と名を改め, Wind Engineering が正式に誕生したのは, 1979 年コロラドでの第 5 回会議からであった。

翻ってわが国では，上記東京での国際会議を契機に土 木・建築分野を中心にこの分野の学際協力が進み, 1976 年にはわが学会の前身である “日本風工学研究会"が設立 された。日本風工学会と名を改めたのは1982年であるが, 研究会設立から学会当初の 4 年間, 計 10 年間の会長を建 築の石崎溌雄先生 (京大防災研教授) が務められた。第 2 代会長はその後 3 期 6 年間, 当初から理事であった私が
務めた。すなわち私もこの学会の設立者の一人であった が，当初から今と同じく，士木，建築分野のほかに，電 力, 流体, 気象など幅広い分野の方々に加わっていただ いた。風工学の特徵はきわめて学際的であり, かつ対象 が自然災害のような負の側面だけでなく, 風力エネルギ 一の利用, 住環境の改善といった益の面も併せ含んでい ることであろう。ただ，構造技術者にとって構造工学の みならず流体, 気象といった知識も必要であるため, 敷 居の高さを感じる方もおられよう。

ともかく, わが国では台風, 突風, 季節風による自然 災害が問題になることが多い。戦後しばらくして長大橋, 高層ビルの建設が盛んになった状況下で学会設立当初か ら風工学研究は隆盛を極め, 研究者数, 発表論文数, 風 洞などの研究設備も増加の一途をたどった。その結果, 学会活動レベルが他の先進諸国と較べても高かったと自 負できた。BBAA や CWE のような新しい国際的活動も 日本がリーダーシップをとってきたことは誇れる成果で あった。最近の海外事情は詳らかでないが，充実した内 容の季刊会誌を半世紀近くにわたって出し続けている国 は他にあるだろうか。ただ，最近の会員数の漸減傾向は いささか気になる。私ども橋の分野では長大スパンの建 設が今世紀に入って急減したという事情もあろうが，科 学技術の目覚しい発展によってさまざまな道具立てを手 にすることができるようになった今, 先見性を持って新 たな課題に取り組も努力が必要ではなからうか。
* (一財) 橋梁調査会理事長 President, Japan Bridge Engineering Center 東京大学/埼玉大学 名誉教授 Professor Emeritus, The University of Tokyo/ Saitama University
日本風工学会 名誉会員・元会長

Honorary Member and Former President, JAWE 